\title{
Factors Associated with Job Stress of Software professionals in Bangalore city
}

\author{
Ankireddy Sailaja ${ }^{1}$, Dr.T.Narayana Reddy ${ }^{2}$, Dr.D.Pradeep Kumar ${ }^{3}$ \\ 1 Assistant Professor, Department of Management, Sir Vishweswaraiah Institute of Science and Technology, \\ Madanapalle-517325, Andhra Pradesh, India. \\ 2 Head, Department of Humanities, Jawaharlal Nehru Technological University,Anantapur-515003 , Andhra \\ Pradesh, India. \\ 3 Professor \& Head, Department of Business Management Studies, Madanapalle Institute of Technology and \\ Science. Madanapalle, 517325. Andhra Pradesh, India.
}

\begin{abstract}
Software job is stressful job. It is difficult to say what factors contribute to this stress, because job stress may be caused by a complex set of reasons. Some of the most visible factors of job stress are Work Stressors, Role Stressors, Personal development stressors, Interpersonal relation Stressors and Organizational climate Stressors. The present study investigates factors that contributed to stress and relations among the stress factors of software professionals. An analysis of about 100 professionals serving different software companies was carried out. The gathered data was analyzed using descriptive, correlation and regression analyses. The study reveals that the correlation of organisational climate with all other stressors and that the software professionals are much concerned of accommodating themselves to different roles in performing the work assigned. A regression is fitted with different stress factors.
\end{abstract}

Key Words: Job Stress, Software employees, Correlation, Regression analysis.

\section{Introduction:}

The concept of stress was first introduced in the life sciences by Selye Hans in 1936. It was derived from the Latin word 'stringere'; it meant the experience of physical hardship, starvation, torture and pain. According to the National Institute for Occupational Safety and Health, Job stress is commonly defined as the harmful physical and emotional responses that occur when the demands of the job exceed the capabilities, needs or resources of the worker. Job stress results from the interaction of the worker and the conditions of the work. Views differ on the importance of worker characteristics versus working conditions as the primary causes of job stress.

Software job is stressful job since the software development process is quite complex, from understanding of clients' requirement to the maintenance phases, different sets of knowledge and skills are required. Hence, various personnel are involved in a cycle, like business developers, project managers, system analysts, programmers, coders, and quality assurance people; apart from other consultants who provide the insight into the domain knowledge of the area in which software is developed.

The factors leading to stress among individual are called as stressors. Various factors have been identified as stressors among software development personnel. However, we have identified five major stressors through the literature review that are crucial in determining the job related stress among professionals. These factors are work stressors, role stressors, Personal development stressors, interpersonal relationship stressors and organizational climate stressors.

\section{Literature review:}

Selye Hans, in 1936 defined stress as "the non-specific response of the body to any demand placed upon it" in attempting to extrapolate his animal studies to humans so that people would understand what he meant. As noted by Robbins et al (1998) Job stress has been recognized as one of the crucial work place problems in different countries around the globe. Sauter and Murphy (1999) defined work stress as " the harmful physical and emotional responses that occur when the requirements of the job do not match the capabilities, resources or need of the worker".Several studies have shown that occupational stress can lead to various negative consequences for the individual and the workplace (Oginska-Bulik,2006). Stress in the workplace can ultimately rob people of their spirit and passion for the job, resulting in impaired individual functioning (Fairbrother \& Warn, 2003), low motivation (Vakola \& Nikolaou, 2005), decreased morale (Faragher et al, 2004; Salmond \& Ropis, 2005), dampened initiative, reduced interest in working (Fairbrother \& Warn,2003), high absenteeism rates (Ho,1997), decreased capacity to perform (Michie, 2002), poor job performance (Jepson \& Forrest, 2006), reduced efficiency (Shain,1999), poor quality control, decline in 
productivity (Faragher et al, 2004;) and low quality products and services (Vakola \& Nikolaou,2005). Occupational stress can also lead to loss of a sense of responsibility, lack of concern for colleagues (Fairbrother \& Warn, 2003), breakdown in personal relations with colleagues, low levels of mutual understanding and tolerance, irritability, indecisiveness, poor communication, poor interpersonal skills, feelings of isolation and alienation (Brown et al, 2002), loss of capability to regulate one's own emotions (Oginska-Bulik, 2005), reduced job satisfaction, poor organizational commitment (Vakola \& Nikolaou, 2005), problems of staff retention (Jepson \& Forrest,2006), early retirement (Michie,2002), and premature death (Rodham \& Bell 2002). Hoonakker (2005) argued about different factors associated with quality of working life and turnover. He pointed out that work and family life, if spill over to each other, create different psychological demands and cause stress and depression. Googins (1987) also reported the same phenomena. Other causes and consequences of stress have been assessed by different studies like: physical ailments by Frone et al. (1997), life satisfaction by Higgins et al. (1992), turnover at workplaces by Greenhaus et al. (1997), and job satisfaction by Netemeyer et al. (1996). In their works, Fujigaki (1993) and Furuyama (1994) have tried to measure the causes of stress among programmers and the impact of the stress in creating different types of errors in their work. Significantly, they have mentioned that stress is present in almost all phases of software development life cycle.

\section{Objectives of the study:}

The present study carried with the following objectives:

1. To know the demographic profile of the software employees.

2. To measure the level of stress among software professionals.

3. To measure the relationships among the selected stress factors of software professionals.

4. To fit a regression to determine the stress.

\section{Methodology:}

Selection of factors causing stress is adopted from heavy literature review is being studied. The instrument developed by Telaprolu and George (2005) was adopted in this study to measure the level of stress among the software professionals. A pilot study was conducted on 25 members of software employees in Bangalore. The reliability of overall scale was 0.8568 . Every item in the instrument is logically linked with objectives of the study, backed by the literature review, which ensure its validity. The instrument consists of two parts. First part consists of questions related to demographic variables such as gender, age, salary, designation, type of the organization etc. Second part consists of questions related to measurement of various stressors identified as potential source of stress. This part consisted of 25 statements and had a five-point scale as 'Always', 'frequently', 'sometimes', 'rarely', and 'never' with scorings as 5,4,3,2 and 1 respectively. The range of score was 25 to 125 . Based on the total scores, the level of stress was quantified as follows.

\begin{tabular}{|l|l|l|}
\hline Category & Range & Score \\
\hline Low stress & $25-50$ & 1 \\
\hline Moderate stress & $51-75$ & 2 \\
\hline High stress & $76-100$ & 3 \\
\hline Extreme stress & $101-125$ & 4 \\
\hline
\end{tabular}

\section{Limitation of the study:}

There are many variables which are related to job stress. Every individual responds differently to the stress they face depending on their personality characteristics, their unique experience in the workplace and their coping strategies. Stress is an interactive process which involves these factors. In this research, the researcher merely focuses on work related stress, Role stress, personal development stress, organizational climate stress and its relationship with selected individual characteristics. The extraneous stressors beyond the job stress are not discussed. Another limitation which would affect the results is stress levels may not necessarily remain constant. The software professionals may feel less stressful when things are going well, but the scores may differ when things are going badly.

\section{Analysis and Interpretation of the data:}

The results of the analysis of the collected data are presented below:

\subsection{Socio-demographic variables of respondents:}

The age of participants in this study ranged from 21 to 43 years old with an average of 28.7 years and 4.2 years of standard deviation. Their experience ranged between 1 and 15 years with an average of 7.5 years and standard deviation of 1.5 years. 
Table-1: The frequency distribution of software professional's socio-demographic variables.

\begin{tabular}{|c|c|c|c|}
\hline Particulars & Category & Frequency & Percentage \\
\hline Gender & $\begin{array}{l}\text { Male } \\
\text { Female }\end{array}$ & $\begin{array}{l}75 \\
25\end{array}$ & $\begin{array}{l}75 \% \\
25 \%\end{array}$ \\
\hline Age & $\begin{array}{l}\text { Below } 25 \\
25-30 \\
30-35 \\
\text { Above } 35\end{array}$ & $\begin{array}{l}27 \\
45 \\
22 \\
06\end{array}$ & $\begin{array}{l}27 \% \\
45 \% \\
22 \% \\
06 \% \\
\end{array}$ \\
\hline Marital Status & $\begin{array}{l}\text { Single } \\
\text { Married }\end{array}$ & $\begin{array}{l}50 \\
50\end{array}$ & $\begin{array}{l}50 \% \\
50 \%\end{array}$ \\
\hline Education & $\begin{array}{l}\text { U.G } \\
\text { P.G }\end{array}$ & $\begin{array}{l}47 \\
53\end{array}$ & $\begin{array}{l}47 \% \\
53 \%\end{array}$ \\
\hline Designation & $\begin{array}{l}1 \\
2 \\
3\end{array}$ & $\begin{array}{l}32 \\
43 \\
25 \\
\end{array}$ & $\begin{array}{l}32 \% \\
43 \% \\
25 \% \\
\end{array}$ \\
\hline Experience & $\begin{array}{l}0-5 \text { years } \\
5-10 \text { years } \\
10-15 \text { years }\end{array}$ & $\begin{array}{l}52 \\
40 \\
08 \\
\end{array}$ & $\begin{array}{l}52 \% \\
40 \% \\
08 \% \\
\end{array}$ \\
\hline Working days per week & $\begin{array}{l}5 \text { days } \\
6 \text { days }\end{array}$ & $\begin{array}{l}88 \\
12\end{array}$ & $\begin{array}{l}88 \% \\
12 \%\end{array}$ \\
\hline Working Shifts & $\begin{array}{l}\text { Day } \\
\text { Night } \\
\text { Alternative }\end{array}$ & $\begin{array}{l}81 \\
04 \\
15 \\
\end{array}$ & $\begin{array}{l}81 \% \\
04 \% \\
15 \% \\
\end{array}$ \\
\hline Working Hours & $\begin{array}{l}7 \text { hours } \\
8 \text { hours } \\
8-9 \text { hours } \\
9-10 \text { hours }\end{array}$ & $\begin{array}{l}21 \\
40 \\
22 \\
17\end{array}$ & $\begin{array}{l}21 \% \\
40 \% \\
22 \% \\
17 \% \\
\end{array}$ \\
\hline Annual Salary & $\begin{array}{l}\text { Less than } 5 \text { lacks } \\
5-10 \text { lacks } \\
10-15 \text { lacks } \\
15-20 \text { lacks } \\
20 \text { lacks above }\end{array}$ & $\begin{array}{l}30 \\
40 \\
22 \\
03 \\
05\end{array}$ & $\begin{array}{l}30 \% \\
40 \% \\
22 \% \\
03 \% \\
05 \% \\
\end{array}$ \\
\hline Family Type & $\begin{array}{l}\text { Nuclear } \\
\text { Joint }\end{array}$ & $\begin{array}{l}64 \\
36\end{array}$ & $\begin{array}{l}64 \% \\
36 \%\end{array}$ \\
\hline
\end{tabular}

(Basis: Primary Data)

It could be evidence from the table- 1 that the sample consists of $75 \%$ of male respondents and $25 \%$ of female respondents. Age of respondents are bifurcated in to four divisions, $27 \%$ of the respondents are less than 25 years, $45 \%$ of the respondents are between 25 and 30 years, $22 \%$ are between 30 and 35 years and $6 \%$ are the age group of above 35 years. Marital status of the respondents shows that $50 \%$ are married and $50 \%$ are un-married. The sample consists of $47 \%$ respondents are undergraduates and the reaming $53 \%$ are post-graduates. The experience shows that $52 \%$ of the respondents have less than 5 years, $40 \%$ of the respondents have 5 to 10 years, $8 \%$ are of 10 to 15 years of experience. $88 \%$ of the respondents are working 5 days per week and $12 \%$ are working 6 days per week. 30\% respondents are drawing salary less than Rs 5 lakhs per annam, $40 \%$ are drawing between 5 to 10 lakhs and $22 \%$ are drawing salary in the range of 10 to 15 lakhs. $64 \%$ of the respondents are from nuclear family and $36 \%$ are having joint family.

\subsection{Descriptive Analysis:}

Table-2 shows the average level of intensity of each subscale along with their standard deviation. On the basis of coefficient of variance (C.V), the factors that are contributing more towards jobs stress are 'Work Stressors' (mean 3.88), 'Role Stressors' (mean 3.40) and 'Interpersonal relation Stressors'(mean 3.39). While next two factors of job stress are, 'Personal development stressors' (mean 3.35) and 'Organizational climate Stressors' (mean 3.15). Hence, major factors contributing towards the job stress are Work stressors and Role stressors.

Table 2: Descriptive Analysis of Factors:

\begin{tabular}{|l|c|c|c|c|c|}
\hline \multicolumn{1}{|c|}{ Factors } & Min & Max & Mean & S.D & Co-efficient of variation \\
\hline Work Stressors & 3 & 5 & 3.88 & 0.59 & 15.21 \\
\hline Role Stressors & 2 & 5 & 3.40 & 0.74 & 21.76 \\
\hline Personal development stressors & 2 & 5 & 3.35 & 0.67 & 20.00 \\
\hline Interpersonal relation Stressors & 2 & 5 & 3.39 & 0.71 & 20.94 \\
\hline Organizational climate Stressors & 1 & 5 & 3.15 & 0.82 & 26.03 \\
\hline
\end{tabular}




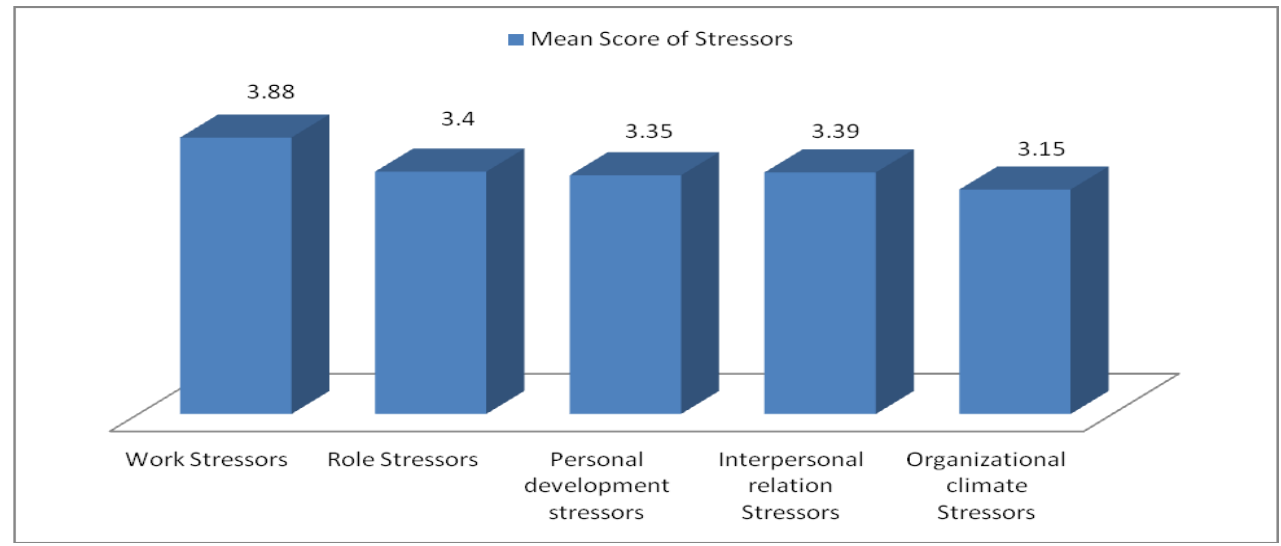

\subsection{Correlation Analysis:}

Table-3, The correlation matrix reveals that the highest correlation is found in 'Role stressors' and 'Organizational climate Stressors' i.e. 0.516, and 'Work stressors' and 'Role stressors' are also highly correlated, i.e 0.505 . On the other hand, there is a weak correlation between 'Work Stressors' and 'Interpersonal relation Stressors. One factor 'Organizational climate Stressors' has very high correlation with almost all other factors. Hence, this suggests that Organizational climate is disturbed with the other stressors if on rise. It is a mixture of norms, values, expectations, policies and procedures that exist in an organization which influence the work motivation, commitment, performance and performing different roles in the work environment. The employees in performing the work assigned, are required to perform certain roles which rise the inconvenience to them and thus the rise in stress levels.

Table 3: Correlation Matrix of Factors:

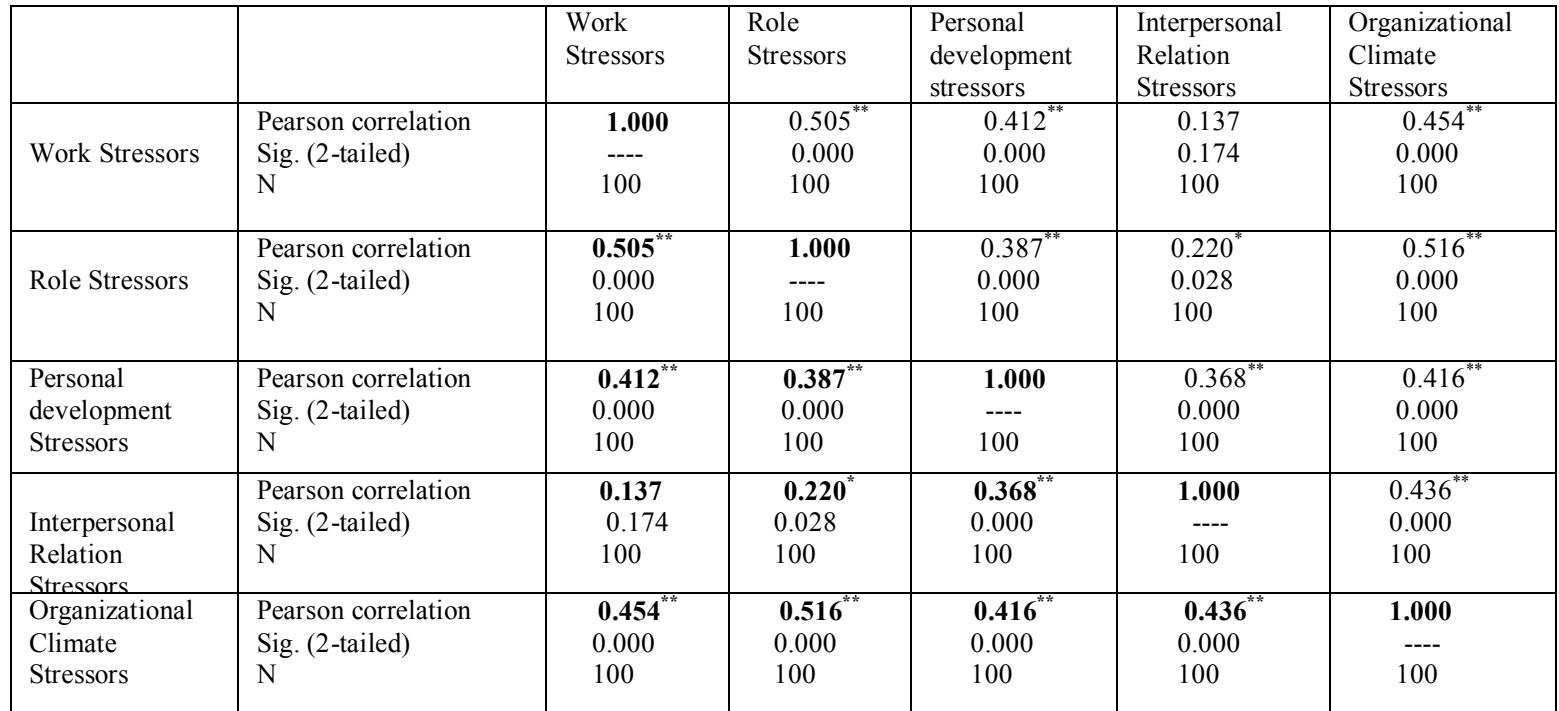

Correlation is significant at the 0.01 level (2-tailed).

* Correlation is significant at the 0.05 level (2-tailed). 


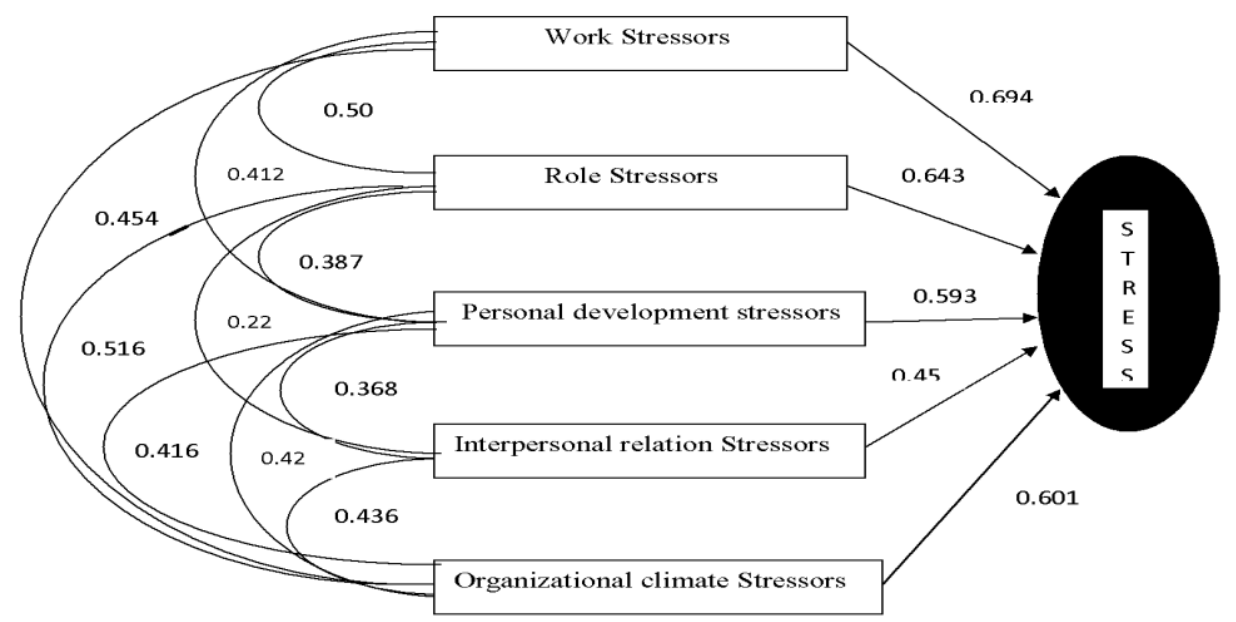

\subsection{Regression Analysis:}

Table-4: R-square of the model and result of ANOVA for overall stress

\begin{tabular}{|l|l|l|l|l|l|l|}
\hline Model & $\mathrm{R}$ & $\mathrm{R}$ Square & $\begin{array}{l}\text { Adjusted } \mathrm{R} \\
\text { Square }\end{array}$ & $\begin{array}{l}\text { Standard Error of the } \\
\text { Estimate }\end{array}$ & $\begin{array}{l}\text { ANOVA } \\
\text { F-value }\end{array}$ & $\mathrm{p}$-value \\
\hline 1 & 0.853 & 0.728 & 0.713 & 0.28 & 50.258 & 0.000 \\
\hline
\end{tabular}

Here the stress level is taken as the dependent variable and all the 5 factors causing stress taken as independent variables. Regression analysis is performed separately for the stress factors. All the 5 factors have $71.3 \%$ influences on job stress.

Table-5: Regression analysis of factors causing stress of software professionals.

\begin{tabular}{|c|c|c|c|c|c|}
\hline \multirow[b]{2}{*}{ Model } & \multicolumn{2}{|c|}{ Un standardized Coefficients } & \multirow{2}{*}{$\begin{array}{c}\text { Standardized } \\
\text { Coefficients } \\
\text { Beta } \\
\end{array}$} & \multirow[t]{2}{*}{$\mathrm{t}$} & \multirow[t]{2}{*}{ Sig. } \\
\hline & B & Std.Error & & & \\
\hline 1 (constant) & 0.455 & 0.227 & & 2.004 & 0.048 \\
\hline Work Stressors & 0.362 & 0.060 & 0.402 & 6.021 & 0.000 \\
\hline Role Stressors & 0.187 & 0.049 & 0.259 & 3.818 & 0.000 \\
\hline Personal development stressors & 0.161 & 0.051 & 0.204 & 3.168 & 0.002 \\
\hline Interpersonal relation Stressors & 0.163 & 0.047 & 0.217 & 3.493 & 0.001 \\
\hline Organizational climate Stressors & $6.849 \mathrm{E}-02$ & 0.046 & 0.106 & 1.485 & 0.141 \\
\hline
\end{tabular}

a Dependent Variable: JOB STRESS

Therefore $Y=\boldsymbol{\beta}_{0}+\boldsymbol{\beta}_{1} \mathbf{X}_{1}+\boldsymbol{\beta}_{2} \mathbf{X}_{2}+\boldsymbol{\beta}_{3} \mathbf{X}_{3}+\boldsymbol{\beta}_{4} \mathbf{X}_{4}+\boldsymbol{\beta}_{5} \mathbf{X}_{5}+\boldsymbol{\varepsilon}_{\mathrm{i}}$

$$
\text { i.e } \mathbf{Y}=0.455+0.362 \mathbf{X}_{\mathbf{1}}+0.187 \mathbf{X}_{\mathbf{2}}+0.161 \mathbf{X}_{\mathbf{3}}+0.163 \mathbf{X}_{\mathbf{4}}+6.849 \mathrm{E}-02 \mathbf{X}_{\mathbf{5}}+\boldsymbol{\varepsilon}_{\mathbf{i}}
$$

Table-5,shows that work stressors, Role stressors, Personal development stressors, Interpersonal relation stressors have significant effect on stress level as for all the cases $p<0.05$. Further among all these factors work stressors and Role stressors have more effect as standard beta $>0.25$ followed by Interpersonal relation Stressors $($ beta $=0.217)$, Personal development stressors $($ beta $=0.204)$ and the rest of the factor Organizational climate Stressors has no significant effect on stress level. 


\section{Conclusions:}

The results revealed that the job stress level of the IT professionals was generally moderate with some experiencing high level of stress. The four factors Work Stressors, Role Stressors, Personal development stressors, Interpersonal relation Stressors and Organizational climate Stressors considered in this study contributing towards the job stress of software professionals do have equal weight and contribute differently. From the descriptive analysis major factors contributing towards the job stress identified are Work stressors and Role stressors. One factor 'Organizational climate Stressors' has high correlation with almost all other factors but its impact on job stress is less. The correlation matrix reveals that the highest correlation is found between 'Role stressors' and 'Organizational climate Stressors' i.e. 0.516. Organizational climate is one of the major components which determines the attitudes and behavior of its members in an organization. To perform certain roles in the organization or to obtain employee co-operation in achieving organizational objectives, the management of all organizations must satisfy various needs of the employees. Through its actions and decisions-making style of leadership, an organization influences the feelings, attitudes and behavior of its members. Such actions of the management result in creating a unique organizational climate.

The fitted regression line $\mathbf{Y}=0.455+0.362 \mathbf{X}_{\mathbf{1}}+0.187 \mathbf{X}_{\mathbf{2}}+0.161 \mathbf{X}_{\mathbf{3}}+0.163 \mathbf{X}_{\mathbf{4}}+6.849 \mathrm{E}-02 \mathbf{X}_{\mathbf{5}}+\boldsymbol{\varepsilon}_{\mathbf{i}}$ gives the expected stress score of software professional. Where $\mathbf{X}_{1}=$ Work Stressors, $\mathbf{X}_{2}=$ Role Stressors, $\mathbf{X}_{\mathbf{3}}=$ Personal development stressors, $\mathbf{X}_{\mathbf{4}}=$ Interpersonal relation Stressors $\mathbf{X}_{\mathbf{5}}=$ Organizational climate Stressors and $\boldsymbol{\varepsilon}_{\mathbf{i}}=$ error term. The coefficient for organizational climate stressors is observed to be very less. This is attributed to the fact that the impact of organizational climate is already measured with the coefficients of other stressors as organizational climate has a very significant impact on every other stressor within the organization. To address the organizational climate stress, the management has to address each of the other stressors which would automatically reduce the organizational climate stress.

\section{References:}

[1] Aditi, N. and Kumari, B., 2005, Impact of personality patterns and employment status on psychological stress tolerance of women in Kerala. Indian Psy. Rev., 64(2): 103-108.

[2] Agrawal, U. N., Malhan, N. K. and Singh, B., 1979, Some classifications of stress and its applications at work. Ind. J. Indus. Rel., 15(1):41-50

[3] Dr Amanat Ali Jalbani \& M Zaki Rashidi (2009), 'Job Stress among Software Professionals in Pakistan: A Factor Analytic Study', Journal of Independent Studies and Research, ISSN: 1998 - 4162

[4] A.K. Sharma, S. Khera, J. Khandekar Computer Related Health Problems Among Information Technology Professionals in Delhi Indian Journal of Community Medicine Vol. 31, No. 1, January - March, 2006

[5] George Rodrigues and purushotham gowda (2011), " A study of organizational climate in professional college libraries and information centres in Mangalore city”,Annals of library and information studies, Vol.58, march 2011,pp 24-33.

[6] Jayashree nayak and Dr.Susheela P. Sawkar., 2008,Factors influencing stress and coping strategies among the degree college teachers of Dharwad city, Karnataka

[7] Keenan .T.J.and Newton, (1985). Stressful Events, Stressors and Psychological Strains in Young Professionals Engineers, Journal of Occupational Behaviour, Vol. 6, pp. 141-6.

[8] K. S. Rajeswari, R. N. Anantharaman April 2003 SIGMIS CPR '03 Development of an instrument to measure stress among software professionals: factor analytic study

[9] K. S. Rajeswari and R. N. Anantharaman Role of Human-Computer Interaction Factors as Moderators of Occupational Stress and Work Exhaustion published in International Journal of Human-Computer Interaction 2005, Vol. 19, No. 1, Pages 137-154

[10] Dr. Manidrajit singh pabla," occupational stress amongst teachers of professional colleges in Punjab",sept 2012,volume.1,issue.9, Indian journal of research,ISSN-2250-1991

[11] Melchior M, Caspi A, Milne BJ, Danese A, Poulton R, Moffitt TE. Work stress precipitates depression and anxiety in young, working women and men. Psychol Med. 2007;37:1119-29.

[12] Moshin Aziz, (2004), Role Stress among Women in the Indian Information Technology Sector, Women in Management Review, Vol. 19, No. 7, pp. 356-363.

[13] McGrath, J. E. (1976). Stress and behavior in organizations. In M. D. Dunnette (Ed.),Hand- book of Industrial and Organizational Psychology. Chicago, IL: Rand McNally, 1351-1395.

[14] Netmeyer RG, Boles JS, McMurrian R. Development and validation of work-family conflict and family-work conflict scales. J Appl Psychol. 1996;81:400-10.

[15] Wiley, C. (2000, June). A synthesis of research on the causes, effects, and reduction of Strategies of teacher stress. Journal of Instructional Psychology, 27(2): 80-87G. 2nd ed. vol. 3, J. Peters, Ed. New York: McGraw-Hill, 1964, pp. 15-64. 